\title{
An assessment of the abundance and distribution of the Titicaca Flightless Grebe Rollandia microptera on Lake Titicaca and evaluation of its conservation status
}

\author{
ARI E. MARTINEZ, DAVID F. ARANIBAR and EDWIN R. GUTIERREZ
}

\section{Summary}

Censuses were conducted from 15 June to 6 July and from 15 to 24 October 2003 throughout Lake Titicaca to determine the current distribution and abundance of the Titicaca Flightless Grebe Rollandia microptera. We surveyed 22 of an estimated 25 local population distribution ranges. We defined these as shallow offshore feeding areas in combination with coastal beds of tule-rushes (Schoenoplectus tatora). At this large spatial scale we found variously sized populations of grebes in all 22 of the areas surveyed and a negative correlation between the total area of tule-bed within each area and grebe density. Absolute counts of grebes pooled across all sites produced a total of 2,582 individuals on Lake Titicaca. Given that some sites were either partially surveyed or not surveyed at all we feel that this is an underestimate of the total lake population. Limitations in methodologies used precluded the classification to development stage of approximately $43 \%$ of the individuals counted. Among the remaining $57 \%$ of the individuals counted we identified 732 mature adults within the total population of Lake Titicaca. When combined with information from other sources and current knowledge of habitat fragmentation our results support the classification of the species in the IUCN Red List as Endangered under criterion C2a. Of 20 local fisherman interviewed on the Bolivian side of Lake Titicaca, 90\% confirmed that individuals of Titicaca Flightless Grebe incidentally drown in their fishing nets although responses varied from weekly to monthly estimates of by-catch. Although this study provides the first estimate of the total population of Titicaca Flightless Grebes on Lake Titicaca, a standardized monitoring programme will be required in order (I) to provide a baseline for the interpretation of future population trends in the context of impacts generated by human activities and (2) to aid in future management decisions for the long-term conservation of the species.

\section{Introduction}

Grebes are among the groups of aquatic bird species most sensitive to environmental change (O'Donnel and Fjeldså 1997). Their relative inability to disperse among aquatic habitats makes them susceptible to human impacts (Fjeldså 1984). The evolution of flightlessness in certain grebes has given rise to five highly range-restricted species in different parts of the world (O'Donnel and Fjeldså 1997, Llimona and del Hoyo 1992). Predictably these species are especially vulnerable to human-induced changes, as exemplified by the Junín Flightless Grebe Podiceps tackzanowski, a species endemic to Lake Junín in Peru and currently listed as Critically Endangered. Within the last 
30 years alone, two species, the Atitlán Grebe Podilymbus gigas and Colombian Grebe Podiceps andinus, and possibly a third, the Alaotra Grebe Tachybaptus rufolavatus, have become extinct (BirdLife International 2004, O'Donnel and Fjeldså 1997, Llimona and del Hoyo 1992, Collar and Andrew 1988). On account of these trends and alarming anecdotal evidence, attention has recently been drawn to the Titicaca Flightless Grebe Rollandia microptera, a species endemic to the watershed of Lake Titicaca in the altiplano region of northern Bolivia and southern Peru (Hennessey et al. 2003).

A recent unpublished report indicated dramatic declines in several areas where studies and sightings have traditionally reported large numbers of grebes (Engblom et al. 2001). This assessment concluded that the species might be at risk of extinction. It has been suggested that the widespread introduction of monofilament fishing nets has led to the widespread decline of the species (Engblom et al. 2001, E. R. G. and D. F. A. pers. obs.). Others authors have cited the harvesting of reeds and indirect effects of fishing activities as long-term threats faced by the species (O'Donnel and Fjeldså 1997). However, despite the level of concern, there have been no previous studies evaluating the species' formal conservation status. We conducted the first formal large-scale evaluation of the species and its conservation status on Lake Titicaca.

\section{Study area}

Lake Titicaca is a high-altitude $(3,810 \mathrm{~m})$ tropical lake located in the Andean altiplano of Peru and Bolivia. The lake area is approximately $8,100 \mathrm{~km}^{2}$ and has three distinct regions: Lago Grande, Bahía Puno and Lago Chico (Figure 1). Because of its geographical location and large size, the lake maintains a relatively stable year-round climate. The altiplano has a dry season from April to November and a rainy season from December to March.

The flora and fauna of the lake are in large part supported by huge wetlands found along shallow sections of the shoreline, primarily within natural bays. The Titicaca Flightless Grebe is strongly associated with marsh beds comprised primarily of tulerushes Schoenoplectus tatora. This species grows in depths of $1-4 \mathrm{~m}$ of water and emerges up to $2 \mathrm{~m}$ above the waterline, providing valuable foraging and roosting habitat for a number of aquatic bird species, among them the Titicaca Flightless Grebe (Fjeldså 1981). The emergent vegetation is dominated by Schoenoplectus tatora with other plant species such as Miriophyllium elatinoides, Lemna spp., Elodea spp. and Azolla spp. These other macrophytes can typically be found inhabiting various depth-bands, with a complex of Potamogeton spp. occupying the deepest band up to 9 $\mathrm{m}$ depth in Lago Chico and up to $14 \mathrm{~m}$ depth in Lago Grande (Iltis and Mourgiart 1982).

Shallow shelves 3-10 $\mathrm{m}$ deep extend several kilometres offshore at a number of locations around the lake, and have an assemblage of submerged aquatic plants that provide potential foraging habitat for the Titicaca Flightless Grebe. Thus, while the tule-beds are essential breeding and roosting habitat for the Titicaca Flightless Grebe, its feeding grounds can extend far offshore (several kilometres) and up to late morning individuals can be observed far out in open water (Fjeldså and Krabbes 1990, Fjeldså 1981, pers obs.). The tule-beds are included in a large number of communal fishing 


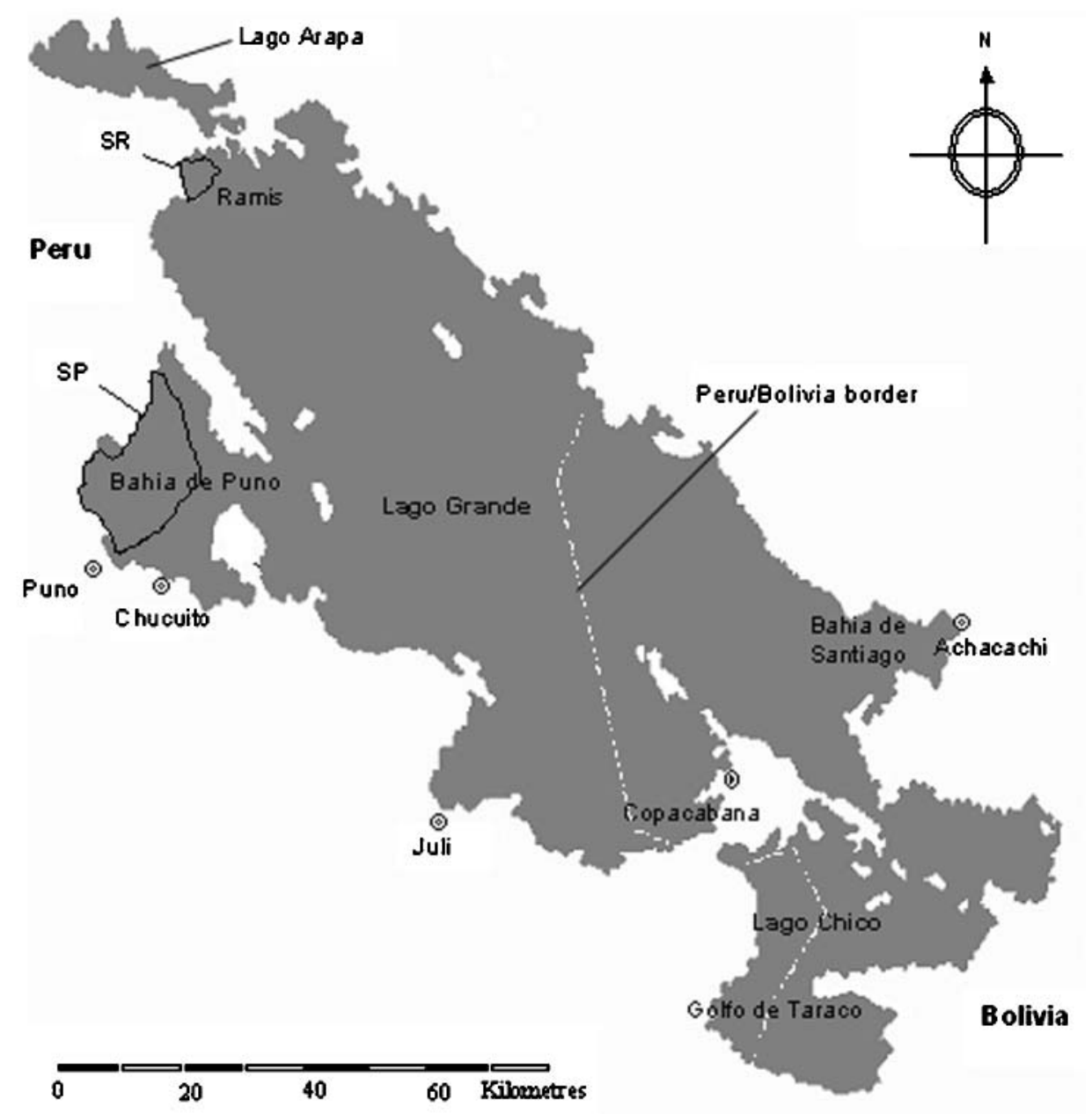

Figure 1. Major geographic features of Lake Titicaca, including Bahía de Puno, Lago Grande, and Lago Chico. SP indicates Sector Puno and SR indicates Sector Ramis of the Lake Titicaca National Reserve. Circles indicate major population centers on the lake. White dashed line indicates the national boundary between Bolivia and Peru.

territories and provide a valuable renewable resource for the subsistence farmers of the Aymara communities (Leviel and Orlove 1990).

Although the majority of individuals of the Titicaca Flightless Grebe are found on Lake Titicaca, the species may also be found on isolated lakes to the immediate north of Lake Titicaca which periodically connect with the lake proper in very wet years. In addition, the species may be found on Lakes Uru Uru and Poopo to the south and the River Desaguadero which connects them to Lake Titicaca.

Studies of diet selection of the Titicaca Flightless Grebe have shown that fish in the genus Orestias comprise up to $94 \%$ of prey, as measured by biomass (Fjeldså 1981). The killifish genus Orestias accounts for 24 of the 26 native fish species found in the lake, the remaining two species being benthic catfish within the genus Trichomycterus 
(Lauzanne 1982). A large number of Orestias species have life cycles associated with the tule-beds, which serve as a habitat for some species and a refuge for juvenile stages of others (Northcote 2000, Vaux et al. 1988, Lauzanne 1982). Not surprisingly the genus Orestias provides the primary prey resource base for the Titicaca Flightless Grebe. The genus Orestias has been estimated to represent $67 \%$ of the annual catch by weight on the Peruvian side of the lake (Leviel and Orlove 1990). There are also two exotic fish species in Lake Titicaca: Basilicthys bonariensis, a silverside or pejerrey introduced in the 1950s, and Onchorhynchus mykiss, a rainbow trout, introduced in the 1940 and supporting a fishery until the 1970 (Vaux et al. 1988). B. bonariensis and O. mykiss have each been estimated to contribute $15 \%$ of the total catch on the Peruvian side of Lake Titicaca (Leviel and Orlove 1990).

\section{Methods}

Census counts for Titicaca Flightless Grebes were conducted from 15 June to 6 July 2003 on the Bolivian shoreline and from 15 to 24 October 2003 on the Peruvian shoreline of Lake Titicaca. Given that the species is an opportunistic breeder and reproduction occurs throughout the year, we believe there to be little difference between census periods. We censused nearly all the shoreline where tule-beds were present but ignored areas devoid of aquatic vegetation as grebes were never found in searches of this habitat (A. E. M. pers. obs.).

Two census techniques were used, applying each where it was more effective:

\section{Absolute counts from the shore}

Where the shoreline provided an unobstructed view of the lake and associated tulebeds, the highest point on the shore was selected, its position recorded with a GPS and all individuals counted with the use of a $25 \times 60 \mathrm{~mm}$ telescope. Where possible, individuals were classified according to development stage: pullus, juvenile, immature, adult. The time taken to count individuals during each sweep was noted. Unfortunately given the sheer vastness of Lake Titicaca and the limitations of time and resources with which to conduct surveys we could not standardize counts to a certain time of day and each point was visited only once. Thus censuses from the shore were conducted throughout the day and this may have led to significant underestimates of individuals in areas censused during the afternoon.

\section{Absolute counts on water}

In a number of areas, the flat shoreline combined with vast tule-beds extending for several kilometres precluded counts from the shore. In such cases the census was conducted by trawling the outer edge of the tule-beds at a distance of $100-150 \mathrm{~m}$ in a motorboat $\left(\sim_{3} \mathrm{~km} / \mathrm{h}\right)$. This technique normally required the work of two observers with binoculars, one counting all birds between the tule-beds and the boat and the other counting only birds further offshore. A GPS position was taken every 15 minutes along transects and the start and end time of all counts were noted. Due to the frequent occurrence of strong afternoon winds on Lake Titicaca during the survey period, all counts were made during the morning, except for Chucuito, a very sheltered bay that allowed counts to be conducted into the afternoon. 


\section{Estimates of the extent of tule-marsh beds around Lake Titicaca}

Given the suggested relationship between grebes and the tule-beds (Fjeldså and Krabbe 1979, Fjeldså 1981) we attempted to quantify the extent of this habitat around Lake Titicaca. Using a satellite image taken in 2001, we used Arcview to trace polygons over all tule-beds and calculate their area. However, as the signatures for aquatic vegetation were not distinct with respect to species, the areas calculated are the complex of tulebeds combined with other species that make up the marsh community assemblage. A considerable number of individual grebes counted in this study were found feeding and on some occasions nesting within these mosaics. In addition, the signatures may also include macrophytes occurring at depths greater than $S$. tatora $\left(>_{4} \mathrm{~m}\right)$ such as Chara spp. and Potamogeton spp.

\section{Determining local populations on Lake Titicaca}

We attempted to define local populations of grebes by delimiting physical areas around the lake that included potential breeding, roosting and foraging habitat within Lake Titicaca and that were relatively isolated from other such areas by expanses of deep open water devoid of any of the above habitat features.

With a bathymetric map we used shallow lake depths as a proxy for the distribution of submerged macrophytes and therefore of potential grebe feeding habitat throughout Lake Titicaca.

We therefore considered sites to be within the species' distributional range if they contained tule-bed complexes within water depths of o to $9 \mathrm{~m}$ (Lago Chico) or o to $14 \mathrm{~m}$ (Lago Grande). Individual grebes observed within any one of these areas were considered part of that local population. The local population distribution ranges had a minimum distance from other units that varied from 3 to $29 \mathrm{~km}$ depending upon the amount of deep open water areas separating such areas. Although individual grebes presumably disperse throughout all parts of the lake we assume that there will be a much higher degree of interaction among grebes within a given tule-bed complex and its associated offshore feeding grounds (within a local population distribution range) than among reed beds separated by stretches of deep water (between local population distribution ranges). In this manner we defined 22 local populations within Lake Titicaca (Figure 2; see Table 1 for site references).

To estimate the size and density of each local grebe population, we computed the sum of count values from all the individual points that fell within a local population distribution range.

\section{Interviews with local people}

A series of 17 questions were used to interview 20 local fishermen on the Bolivian side of the lake with regard to their experience with the Titicaca Flightless Grebe.

\section{Results}

We recorded a total of 2,582 grebes in the 22 accessible population ranges that were completely or partially surveyed (out of the 25 delineated within the lake) (Figure 2, Table 1). We recorded Titicaca Flightless Grebes in all ranges although population size 


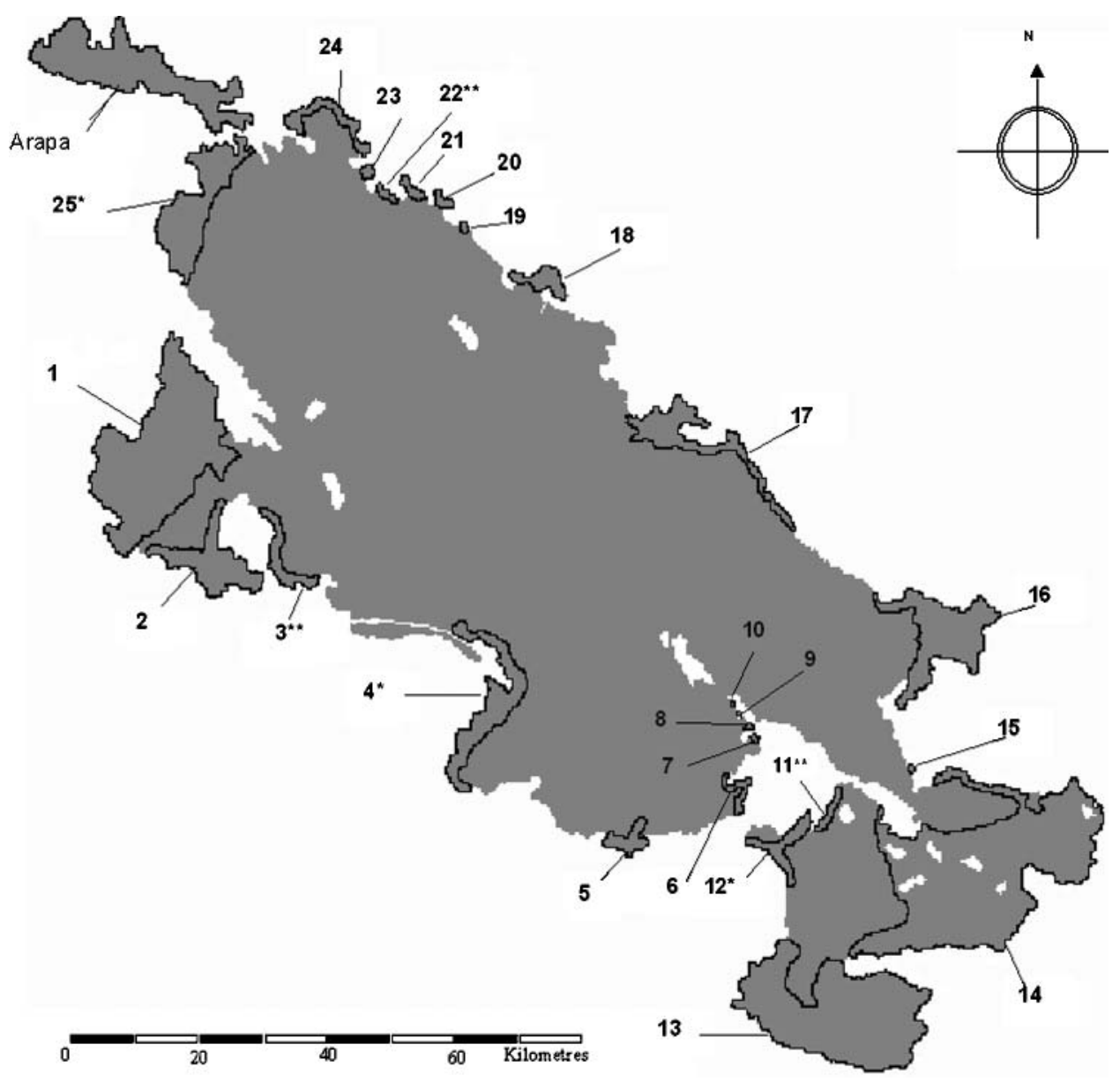

Figure 2. Identification of local population distribution ranges within Lake Titicaca as defined by areas of continuous tule-beds and open-water feeding habitat separated from similar such areas by expanses of deep lake water (see Methods and table 1 ). Refer to Table 1 for detailed information about grebe populations corresponding to numbered sites and site names. Arapa is a lake periodically connected to Lake Titicaca in wet years but otherwise isolated from it. ${ }^{*}$ Part of area not surveyed; ${ }^{* *}$ area not surveyed.

was extremely variable (mean number of individuals 117.5 , SD 144) for the 15 population ranges that were completely surveyed. Estimates of density were also extremely variable, the mean number of grebes being 6.1 (SD 8.1) per square kilometre of lake area within the local population distribution range (Table 1 ). This variation in local population size and density very likely reflects variation in habitat quality and abundance: the area of tule-beds associated with the populations that were completely surveyed ranged from 0.1 to $190.7 \mathrm{~km}^{2}$ with a mean of $29.2 \mathrm{~km}^{2}$ while the area associated with the local population distribution range varied from 0.5 to $456.5 \mathrm{~km}^{2}$ with a mean of $82.8 \mathrm{~km}^{2}$. Because in a number of population distribution ranges we summed several census points, it must be noted that spatial heterogeneity within population ranges is lost. Within these ranges counts were extremely variable, 
Titicaca flightless grebe Rollandia microptera

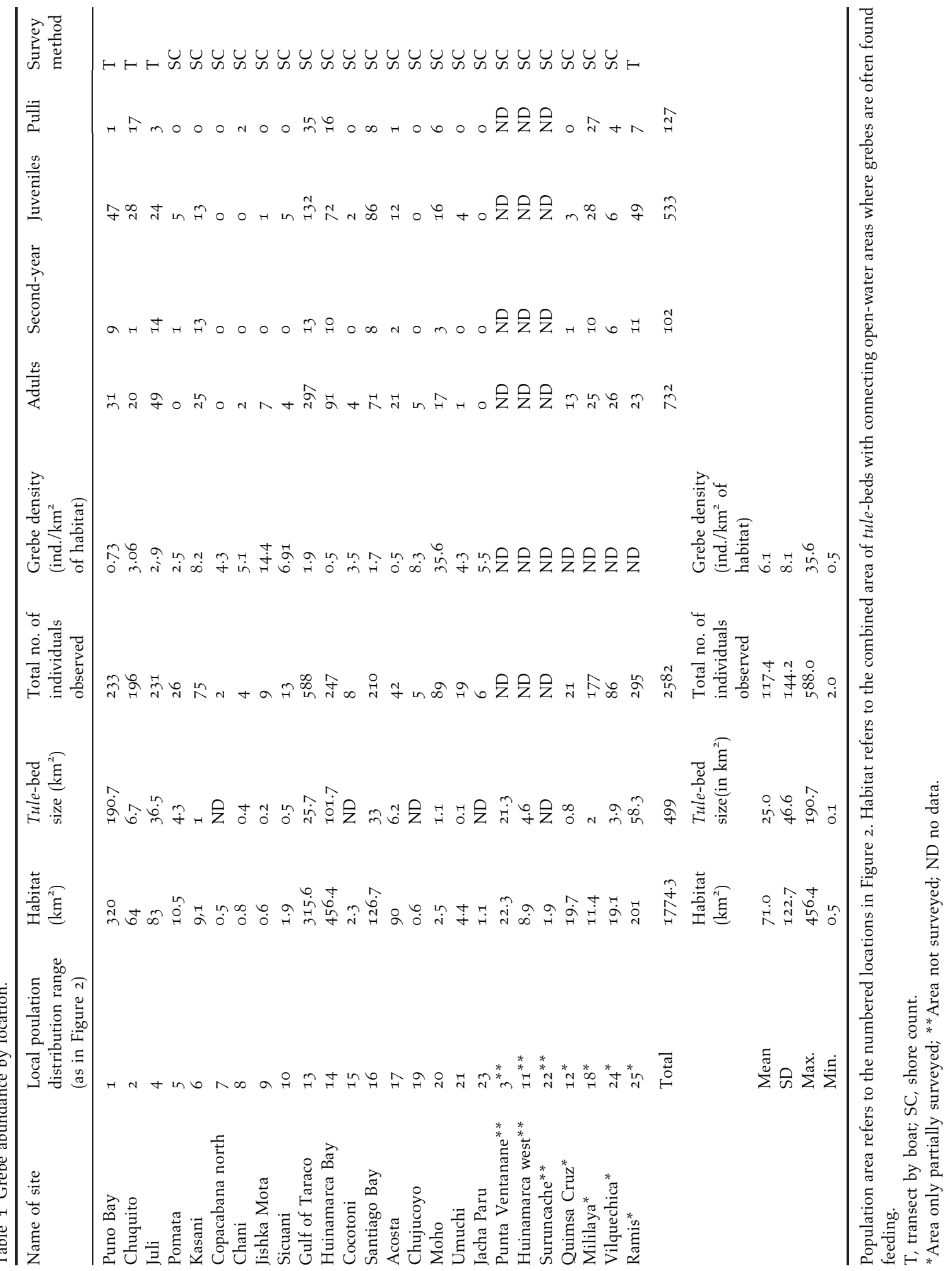


reflecting a number of parameters that are yet to be explored, such as the quality of the tule-beds and offshore feeding grounds, and varying pressure from fishing.

The populations with the highest absolute numbers of grebes were typically located in large shallow bays with extensive tule-beds that were connected to large open-water feeding areas: namely both the Puno and Ramis sectors of the Lake Titicaca National Reserve, Juli, the Gulf of Taraco, Santiago Bay, and Chucuito (Figures 1-3, Table 1). The area south of the Ramis sector very probably has a large population of grebes but, due to suspicion from local farmers, the area could not be completely surveyed by boat as originally planned.

The distinction between adults, second-year birds and juveniles proved difficult as many of the birds counted were far offshore under unfavourable conditions. As a result only $57 \%$ of grebes counted were classified to development stage. Of those identified to development stage we counted a total of 732 mature individuals between the two methodologies (Table 1 ). In addition, 12 of 22 (55\%) of these populations revealed the presence of pulli and therefore of breeding populations in 2003 (Table 1).

We used linear regression to examine population density (number of grebes over total area defined by local population distribution range) as a function of total area of local population distribution range, and to examine population density (number of grebes per square kilometre of tule-bed) as a function of area of tule-beds within each local population distribution range. The data were not normally distributed and were log-transformed. Both analyses revealed a significant negative relationship for grebe density versus total area $\left(R=-0.77, R^{2}=0.59, P<0.001, n=18\right.$; Figure 4 a) and for grebe density versus tule-bed area $\left(R=0.80, R^{2}=0.65, P<0.001, n=14\right.$; Figure 4 b).

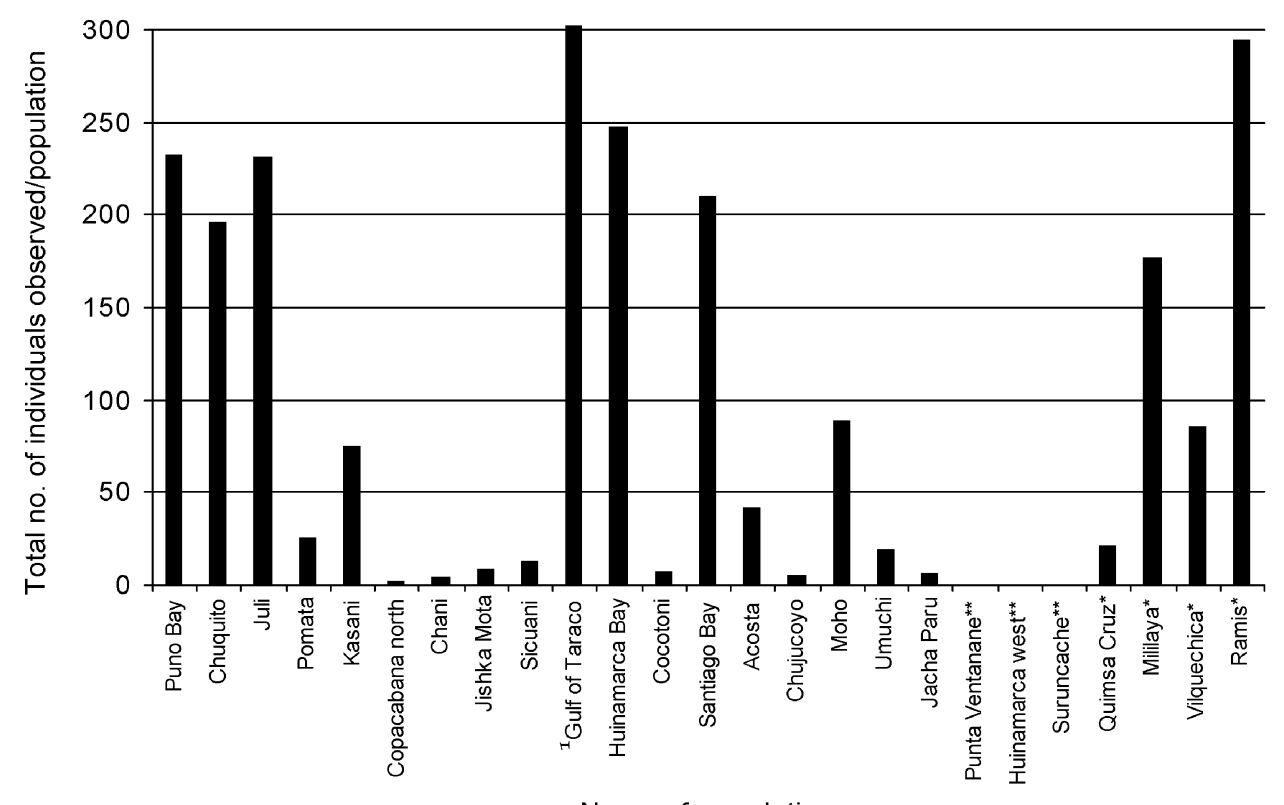

Name of population

Figure 3. Total number of grebes observed in each population. See Table 1 and Figure 3 for corresponding population number and location on map. ${ }^{1}$ Value for Gulf of Taraco is 588 individuals. 
By-catch

Of the Aymara fishermen from five communities questioned, 100\% of those using gill nets confirmed finding Titicaca Flightless Grebes drowned as by-catch. Nine fishermen $(45 \%)$ stated that they found individuals drowned in their nets on a weekly basis, whereas seven $(35 \%)$ said that they found grebes in their nets on a monthly basis, and the remainder only incidentally. On the Bolivian side of Lake Titicaca, fishermen tend to use more nets per capita than their Peruvian counterparts (D. F. A. pers. obs.). Although there is no corresponding information from the Peruvian part of the lake, weekly visits by one of the authors over a 4 month period to the dock of Chucuito where approximately 25 fishermen unload their daily catch revealed approximately two or three drowned aquatic birds per week, among them Titicaca Flightless Grebes, (E. A. G. pers. obs. in 2003). In addition $80 \%$ of the Bolivian fisherman surveyed indicated that they had harvested the eggs of Titicaca Flightless Grebes on at least one occasion.

All 20 of the Bolivian fisherman surveyed indicated that they pursue two target groups of fish: kingfish (Basilicthys bonariensis) and carachi (Orestias spp.). Almost all of those interviewed indicated that the kingfish are caught by setting deeper nets farther offshore while those used to catch carachi are placed in shallow water just off the tule-rush beds. The results of the interviews also suggested that nets targeting Orestias spp. may be more damaging to grebe populations than those targeting $B$. bonariensis, as the latter are often placed in deeper waters and are therefore likely to be out of the range of diving grebes.

All the fishermen interviewed indicated that they harvested tule, while $70 \%$ of them indicated that they harvested tule mainly from July to September.

\section{Discussion}

Grebe populations of varying sizes were widely distributed over the majority of available habitat surveyed. While various sites surveyed in this study contained hundreds of grebes (Table 1, Figure 3 ) it is difficult to interpret these data in a wider context of population decline. Our results revealed variation in grebe density and absolute numbers spanning two orders of magnitude among sites (see Results, Table 1 , Figure 3). In the absence of time-series data that demonstrate the natural variation that the lake population experiences across years, it is not possible at this stage to determine whether the species is declining. Among fishermen, opinions were mixed, some saying there had been more grebes in years past while others maintained there had been no change. However, our survey did not account for the number of years' experience each person had as a fisherman. This information is essential as the trend in recent years has been an increase in the number of local people taking up fishing as an extra source of income. Fishermen with a few years' experience would not have a reference point from which to reflect on grebe numbers past and present.

Although a previous survey (Engblom et al. 2001) reported eight grebes from Bahía de Puno, we counted 233 individuals, which is large compared with any other population in this study. The tremendous variation in estimates for the site reflects the different locales surveyed between studies. In our study, over $95 \%$ of the grebes found within this area were in the north-east corner of the bay where the River Coata flows into Bahía de Puno (Figure 1). In this finger of Bahía de Puno large numbers of grebes 
were seen feeding in open water and within the large areas of Lemna spp. found along the north-east coast of the bay (Table 1 ). Thus most of these individuals were counted outside the large tule-beds of Bahía de Puno and, ironically, in the only portion of Bahía de Puno that does not fall within the boundaries of the Puno sector of the Lake Titicaca National Reserve. The concentration of grebes in this part of the bay may be explained by the entry of the River Coata to the lake, where grebes possibly find increased concentrations of fish.

Certain limitations exist in trying to make comparisons among all the sites surveyed because of different methodologies necessarily employed to overcome problems of accessibility to various sites. In spite of these limitations, we feel that if anything these counts, and the total number of 2,582 individuals, are an underestimate for the number of Titicaca Flightless Grebes found on Lake Titicaca.

What is clear is that an additional source of mortality now exists for the Titicaca Flightless Grebe which was absent 40 years ago: namely the introduction of monofilament gill nets used for fishing by local communities. These nets have almost entirely replaced traditional fishing methods that previously did not affect the grebes (Engblom et al. 2001, O'Donnel and Fjeldså 1997; see Results). The confirmation by local fishermen that grebes drown in their nets (see Results) and the estimate of weekly by-catches in the area around Bahía de Puno suggests that the additional grebe mortality caused by these nets is substantial. The question that most critically needs to be addressed is how grebe populations respond to this added source of mortality.

The effect of fishing nets on grebe populations may not be limited to by-catches in nets. Monofilament fishing nets might greatly deplete the prey base of Orestias spp. and thus play a role in limiting one of the central food resources available to the Titicaca Flightless Grebe. Lake Titicaca has already witnessed the unexplained disappearance of one native fish species, Orestias cuvieri, last observed in 1937. Because the Titicaca Flightless Grebe has a diet predominantly made up of fish, changes in grebe populations may reflect changes in trophic cascades beneath the surface caused by the depletion of this resource through competition with fishermen and non-native piscivores such as B. bonariensis and O. mykiss ( $\mathrm{O}^{\prime}$ Donnel and Fjeldså 1997). According to J. Fjeldså (pers. comm.) grebe populations reproduce quite well in areas where $B$. bonariensis and $O$. mykiss are absent and this is possibly the scenario in the series of shallow lakes to the north of Titicaca that harbour populations of Titicaca Flightless Grebes.

The identification of local population distribution ranges provides a means by which to measure fragmentation within the population of Lake Titicaca. This is important from a conservation standpoint as it provides the first step in assessing the degree to which local populations are at risk of extirpation by taking into account the individual size of each population, the dispersal ability of young grebes, and the extent of isolation from other local populations.

Our surveys suggest tremendous variation in both grebe densities and habitat area among the various populations (see Results, table 1). Clearly, if future management is required for the conservation of the Titicaca Flightless Grebe, consideration of the quality of breeding habitat will be required. A typical example of this is Bahía de Puno, which is the single largest tule-bed on Lake Titicaca. Although its total area is immense, the great majority of the tule-bed is so dense that it is inadequate as a nesting or roosting site for the Titicaca Flightless Grebe. The grebes are more frequently found within mosaics of tule-beds and open habitats that provide easy 
access to open-water feeding areas (Fjeldså 1981, pers. obs.). For very large, dense tulebeds it is most likely the perimeter that is exposed to open-water feeding areas that is most usable by grebes, a small fraction of the total area. This may explain why overall density of grebes decreases with increasing size of tule-beds: the greater the size of the tule-beds, the smaller the portion of usable breeding habitat (Figure $4 b$ ). Identifying parameters of habitat quality such as rush density and proximity of rush habitats to open-water feeding areas would be useful. In addition, identifying communal fishing territories encompassing specific tule-beds that correspond to the grebe populations with the highest conservation potential will also be important in order to coordinate conservation strategies in the context of traditional social structures that currently exists around Lake Titicaca (Leviel and Orlove 1990).
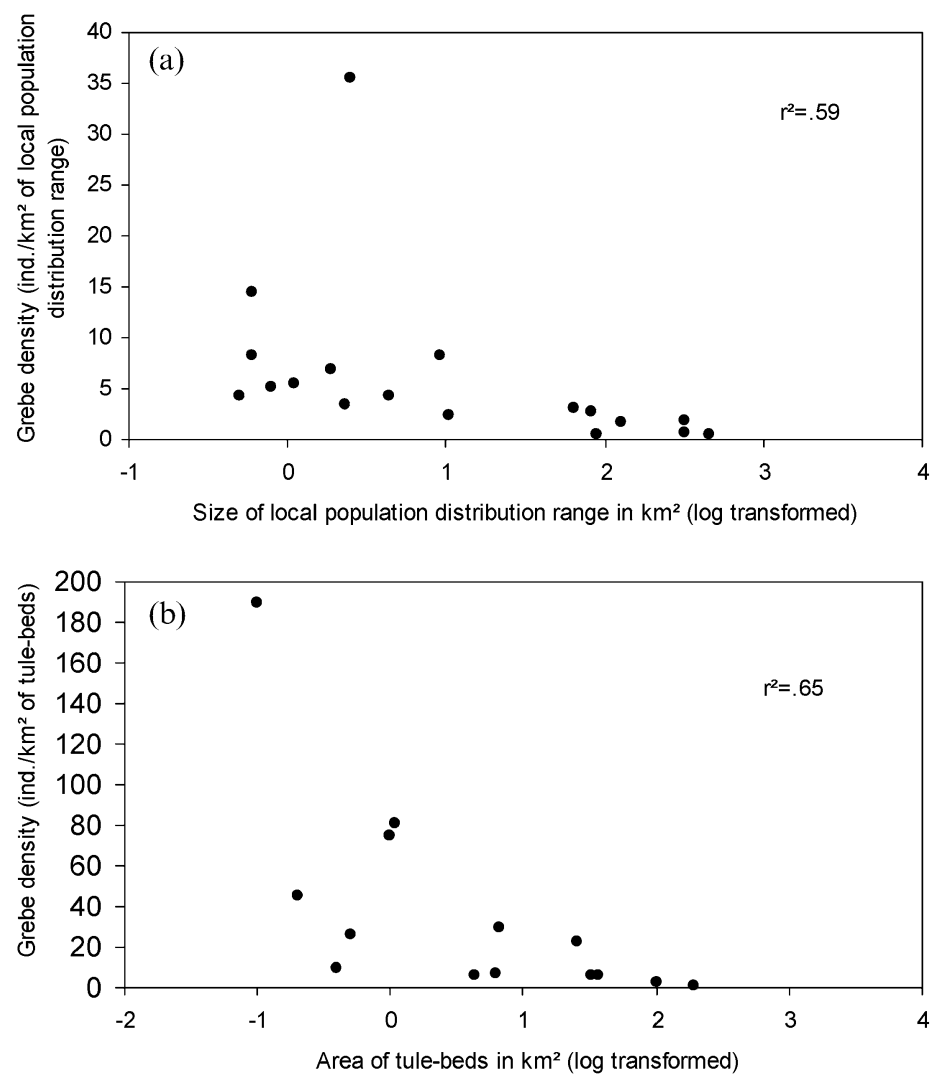

Figure 4. (a) Grebe density (number of individuals per square kilometre of population distribution range) plotted as a function of the total area of the population distributional range (see Methods, Table 1 ). A linear regression was used and the data were log-transformed $(R=$ $-0.77, R^{2}=0.59, P<$.001, $n=18$ ). (b) Grebe density (number of individuals per square kilometre of tule-bed) plotted as a function of the size of the total tule-bed area corresponding to each local population distribution range (see Methods, Table 1 ). A linear regression was used and the data were $\log$-transformed $\left(R=-0.80, R^{2}=0.65, P<0.001, n=14\right)$. 


\section{Other threats to grebe populations}

Several investigators (O'Donnel and Fjeldså 1997, Engblom et al. 2001) have suggested that the harvesting of tule-beds by local communities may be destructive to breeding habitat of the Titicaca Flightless Grebe. These areas have traditionally been used in this manner by Aymara communities for centuries and such use has therefore been part of the environment of the species over such a time period. While traditional methods are still used it is not known to what extent human population growth and the market demand for cattle have changed these patterns and caused a subsequent impact on grebe reproduction. Additional studies quantifying human use over time would do much to clarify this issue.

The population in Bahía de Puno within the Lake Titicaca National Reserve experiences a unique but localized threat. The Uro communities living on the floating islands have traditionally hunted a variety of aquatic birds on a subsistence basis. Recently, however, the Uros have become accustomed to hunting birds, including Titicaca Flightless Grebes, to sell at the market in Puno (D. Aranibar and E. Gutiérrez, pers. obs.) and therefore have turned the hunting into a commercial activity.

\section{Other grebe populations throughout the watershed}

Populations of Titicaca Flightless Grebes are found in a number of other locations throughout the Lake Titicaca watershed: a series of shallow lakes to the north of Lake Titicaca, the River Desaguadero, Lakes Uru Uru and Poopó, and the River Laka Jahuira. Previous surveys from these areas identified 194 adults and second-year birds on the complex of shallow lakes to the north, 17 individuals on the upstream end of the River Desaguadero, and 87 on the River Laka Jahuira (Engblom et al. 2001, Rocha et al. 2002, A. Martinez unpubl. data). Although several areas on Lake Poopó and the River Desaguadero have not been surveyed, the isolated nature and low population numbers on these water bodies suggest that their contribution to the global population is minimal and they should not be the focal point for conservation efforts of the species.

\section{Conservation status of the Titicaca Flightless Grebe}

A number of grebes in this study were not classified to development stage, of which 455 were either second-year birds or adults. For the purposes of this analysis we have assumed that all these 455 birds were mature adults. Therefore, by summing all adults counted in this study on Lake Titicaca and adults counted elsewhere in the Lake Titicaca watershed (Engblom et al. 2001, Rocha et al. 2002), we estimate that there are around 1,600 mature individuals within the global population. This estimate qualifies under main criterion $\mathrm{C}$ of the IUCN Red List criteria for listing a species as Endangered. The largest intact part of the watershed, Lake Titicaca itself, while having a number of local populations, has only one with more than 250 mature individuals (Table 1 ), the rest containing significantly smaller numbers. We feel these estimates qualify under criterion $\mathrm{C}_{2} \mathrm{a}$ of severely fragmented populations for listing the species as Endangered. These findings are consistent with the current status given to the species (BirdLife International 2004). We maintain that the largest number of individuals and local populations that are within the continuous body of water of Lake 
Titicaca represent the greatest opportunities for future research and conservation efforts. We recommend that the following actions be taken:

A monitoring programme should be established using a standardized survey technique in four populations each on the Peruvian and Bolivian sides of Lake Titicaca.

Surveys should be conducted twice a year for a minimum of 5 years with one survey period covering the months of November and December to evaluate peak breeding activity in each of the eight target sites. Surveys should quantify the number of individuals, the development stages of these individuals, the number of breeding pairs, habitat quality (by measuring density of the tule-beds and proximity of such beds to productive offshore feeding areas), and the number and depth of nets in each site. Monitoring sites should include the whole or part of Juli, the Ramis sector of the Lake Titicaca National Reserve, and Chucuito (Peru) and the Golfo de Taraco and Bahía de Santiago (Bolivia).

The Titicaca Flightless Grebe should be the focal species for a more comprehensive periodic census of the aquatic birds of Lake Titicaca. This is especially important given the by-catch of other bird species found in nets and the changes in the fish community that are possibly resulting from intensive fishing and the presence of non-native piscivores.

Local interviews should continue in each site and regular visits to the dock at Chucuito (where fisherman process their daily catch) and at Guaqui (if in fact it is used in a similar manner by fisherman) should additionally try to quantify mortality in fishermen's nets, the age of the birds caught, and where and at what depth the respective nets were set (i.e. in open water or tule-beds). If possible, collecting the specimens for additional data would be extremely useful. Interviews should also quantify the number of individuals of other species of aquatic birds that drown in nets.

Several of the local population distribution ranges mentioned above should be identified for future management action for long-term conservation of the species. The best of the above-named areas would have: a large number of breeding territories in tule-beds (i.e. good breeding habitat) and a minimal number of fishing nets or the best combination above. Net-free areas could quite possibly serve as harvest refugia for the populations of the various species of Orestias spp. currently fished without regulation by local communities, and the feasibility of establishing such a designation should be explored.

By continuing with a longer-term monitoring programme, the biological and sociological data thus obtained will enable: (I) a long-range assessment of the conservation status of the global population of the Titicaca Flightless Grebe and (2) the identification of management steps that need to be taken in order to ensure the longterm conservation of the species and the habitat upon which it depends.

\section{Acknowledgements}

The fieldwork for this project would not have been possible without the financial support personally provided to the Asociación Armonía/BirdLife International in Bolivia by George Jett. We are grateful to the American Bird Conservancy for their support of this conservation effort. In addition we thank R. Wallace and the Wildlife Conservation Society for logistical support. J. Fjeldså tirelessly and promptly offered his input and advice whenever requested. We thank Robert Ridgely for his input to the project. S. K. Herzog and A. B. Hennessey provided much valuable advice on the 
planning and design of the study. S. K. Herzog, A. B. Hennessey and N. Acheson provided valuable comments on the manuscript and R. MacLeod provided valuable discussions on the subject matter. We thank O. Martínez for his assistance in the field in Bolivia and Ramón and Max Katari for their invaluable logistical support. Jaime Sarmiento and Carmen Quiroga of the Universidad Mayor de San Andrés gave advice on where to concentrate efforts, based on their experience. Lisette Correa of the GIS department of the Museo de Historia Natural Noel Kempf Mercado, Universidad Autónoma Gabriel René Moreno was extremely helpful in providing GIS data of Lake Titicaca. The staff of the Lake Titicaca National Reserve in Puno provided logistical support for work conducted in Bahía de Puno. We would also like to thank the Dirección General de Biodiversidad in Bolivia and the Instituto Nacional de Recursos Naturales in Peru for permitting this study to be conducted in the Bolivian and Peruvian parts, respectively, of Lake Titicaca.

\section{References}

BirdLife International (2004) Threatened birds of the world 2004. CD-ROM. Cambridge, U.K.: BirdLife International.

Collar, N. J. and Andrew, P. (1988) Birds to watch: the ICBP world checklist of threatened birds. Cambridge, U.K.: International Council for Bird Preservation. (Technical Publication 8).

Dejoux, C. and Iltis, A., eds. (1982) Lake Titicaca: A synthesis of limnological knowledge. Dordecht: Kluwer.

Engblom, G., Geale, D., Choquehuanca, D. and Ferro, G. (2001) Population survey of Rollandia microptera and other grebes in the Lake Titicaca area. Unpublished report.

Fjeldså, J. (1981) Comparative ecology of Peruvian grebes. Vidensk. Meddr Dansk Naturh. Foren. 143: 125-249.

Fjeldså, J. (1984) Three endangered South American grebes (Podiceps): case histories and the ethics of saving species by human intervention. Ann. Zool. Fenn. 21: 411-416.

Fjeldså, J. and Krabbe, N. (1990) Birds of the High Andes: a manual to the birds of the temperate zone of the temperate zone of the Andes and Patagonia, South America. Zoological Museum, University of Copenhagen, Pp. 66-67.

Hennessey, A. B., Herzog, S. K. and Sagot, F. (2003) Lista anotada de las aves de Bolivia. Fifth edition. Santa Cruz de la Sierra, Bolivia: Asociación Armonía/BirdLife International.

Iltis, A. and Mourgiart, P. (1982) Higher plants: distribution and biomass. Pp. 241-253 in C. Dejoux and A. Iltis, eds. Lake Titicaca: a synthesis of limnological knowledge. Dordecht: Kluwer.

Lauzanne, L. (1982) Native species. The Orestisas. Pp. 405-407 in C. Dejoux and A. Iltis, eds. Lake Titicaca: a synthesis of limnological knowledge. Dordecht: Kluwer.

Leviel, D. and Orlove, B. (1990) Local control of aquatic resources: community and ecology in Lake Titicaca, Peru. Am. Anthropol. 92: 362-382.

Llimona, F. and del Hoyo, J. (1992) Family Podicipedidae (Grebes). Pp. 174-196 in J. del Hoyo, A. Elliot and J. Sargatal, eds. Handbook of the birds of the world. Volume 1. Barcelona, Spain: Lynx Edicions.

Northcote, T. G. (2000) Ecological interactions among an Orestiid (Pisces: Cyprinodontidae) species flock in the littoral zone of Lake Titicaca. Adv. Ecol. Res. 31: 399-420.

O'Donnel, C. and Fjeldså, J. (1997) Grebes: status survey and conservation action plan. IUCN/ SSC Grebe Specialist Group. Gland, Switzerland and Cambridge, U.K.: IUCN.

Rocha, O., Martínez, O. and Quiroga, C. (2002) La avifauna del Lago Poopó. Pp. 76-89 in O. Rocha, ed. Diagnóstico de los Recursos Naturales y Culturales de los lagos Poopó y Uru Uru, Oruro, Bolivia. La Paz, Bolivia: Convencion RAMSAR. WCS/Bolivia. 
Vaux, P., Wurstbaugh, W., Trevino, H., Marino, L., Bustamante, E., Torres, J., Richerson, P. and Alfaro, R. (1988) Ecology of the pelagic fishes of Lake Titicaca, Peru-Bolivia. Biotropica 20: 220-229.

\section{ARI E. MARTINEZ}

Armonía/BirdLife Int., Casilla 3566 Santa Cruz, Bolivia.

DAVID F. ARANIBAR

Instituto de Investigaciones Biológicas y Desarrollo Ambiental, Av. Floral 419-1o Puno, Peru.

EDWIN R. GUTIERREZ

Instituto de Investigaciones Biológicas y Desarrollo Ambiental, Av. Floral 419-1o Puno, Peru.

Received I February 2005; revision accepted 26 September 2005 